Issue no. $25 / 2018$

\title{
ASSESSMENTS AND PROSPECTS FOR THE INTEGRATION OF THE WEST BALKANS. THE CASE OF MONTENEGRO
}

\author{
Assoc. Prof. Dr. Adrian-Gabriel CORPĂDEAN \\ Faculty of European Studies, Babeș-Bolyai University Cluj-Napoca \\ adi_corpadean@yahoo.com
}

\section{DOI:10.24193/OJMNE.2018.25.04}

\begin{abstract}
The article analyses the most significant steps taken by the young Republic of Montenegro towards EuroAtlantic integration, as an interesting case study indicative of the broader region, despite various particularities that have been properly exhibited. From a historiographic standpoint, it draws the country's timeline to independence amid the intricate Yugoslav file, notably by following the role of Milo Đukanovic and his changing attitude towards Slobodan Milošević. NATO membership was achieved amid a considerable amount of political turmoil and international pressure, with the Kremlin's rhetoric proving particularly hostile in this regard, but also with support on the part of key NATO actors. On the other hand, the EU integration bid is undoubtedly more sinuous, with most negotiation chapters opened by this time, albeit in the context of notable political, juridical and economic concerns. One of the most complicated points appears to be the unilateral decision of the Montenegrin government to adopt the single European currency, which indeed sets a precedent in the negotiation process. Particular emphasis in our assessments also lies on the state of administrative reform, with notable strategic endeavours underlined and shortcomings brought forward, including the everchallenging files pertaining to the size of the administrative apparatus, corruption and the need to build a meritocracy-driven public administration system.
\end{abstract}

Keywords: Montenegro, NATO, EU integration, negotiations, administrative reform

\section{Context and independence}

The debate on the future enlargement of the European Union, in the light of the Juncker doctrine and the current more stringent dilemmas stemming from Brexit, the advent of Eurosceptic administrations in both Old and, perhaps more surprisingly and vocally, New Europe, is often regarded as taboo in political circles. That said, it is undeniable that the 
Issue no. $25 / 2018$

Enlargement Policy of the Union remains to date its most spectacular endeavour, engendering and stirring the thorniest debates and triggering some of the most disfiguring frowns in chancelleries formerly setting the tone for East-Central Europe's course of action, prior to 1989. To say that this major undertaking is put on hold is in itself a risky and destabilising deed, all the more so because the efforts made by some governments in the West Balkans, such as the one our study chiefly focuses on, despite strong external constraints is an increasingly hostile context, prompt a need for a more hope and diplomatic acumen-driven rhetoric from the Berlaymont.

Indeed, the case of Montenegro is sufficiently articulate to be worthy of an independent analysis (Corpădean, 2018) through the lens of its EU integration bid and with the support of the documents emitted by both its government and the European Commission, not because we wish to portray it as entirely indicative of the situation of the entire region, but due to the fact that common sense enables us to state that perhaps it is the closest case we have at present to eventual enlargement. The size of the country barely leaves room for an intricate assessment of compliance with the Copenhagen criteria and does create a feeling of simplicity around the subject, but such an observation would be shallow, as numerous factors render Montenegro's EU file interesting. The very fact that it pertains to the former Yugoslav file carries a lot of weight - a country that recently filed for independence, arduously seeking the attributes of self-reliance, with an unusually strong desire to achieve both NATO and EU integration, reminiscent of other countries in East-Central Europe in the mid-1990s, and with economic peculiarities that have no precedent in the EU negotiation process (Alger, 2016; Morrison, 2008).

In actuality, the country does match a certain regional profile from the viewpoint of its recent history, prior to the notable South-Slavic forms of organisation of the $20^{\text {th }}$ century an interesting monarchic period and a declaration of independence emerging from a similar effort to that of Romania (see the events that unfolded in 1877-1878). Such events have already met with ample historiographic analyses, as has the communist experience of the province, as part of the Socialist Federal Republic of Yugoslavia (Herța, 2012, pp. 66-71, 89, 137, 158-159). That is why our study will somewhat gloss over the historical and cultural factors that comprise the Montenegrin identity, as it is our purpose to examine the relations 
Issue no. $25 / 2018$

between the latter and the EU, from the administrative, political and diplomatic angles, so as to paint a realistic picture of the progress (or lack thereof) attained by the country in its bid to join the Union in the foreseeable future, with elements of technical compliance, observations on the adoption of the acquis and some forecasting attempts.

At the risk of overlooking some of the most meaningful twists and turns that have shaped what the country of Montenegro is today, we will briefly follow the events that led to the independence the republic, in order to exhibit what we are convinced is the legitimacy of its EU integration application. It goes without saying that some observations need to be directed towards the country's simultaneous and recently completed NATO bid, which, beyond the chronological parallels we could draw with other countries in the broader region (to which Romania is no stranger), is an indicator of change and sets Montenegro apart from the geopolitical stance of its neighbour and formal hegemon, the Republic of Serbia. This successfully completed endeavour is also indicative of the country's ability to fulfil ample political negotiations, carry out institutional reform and manifest sufficient self-awareness in the international arena.

It is not the same drive and ambition that fuelled Montenegro's stance amid the dismantlement of the Socialist Federal Republic of Yugoslavia (Herța, 2015, pp. 164-185), albeit we do acknowledge that it occurred at a time when no Euro-Atlantic integration prospects were genuinely looming on the horizon for any country in the area. Hence, the referendum of 1 March 1992 revealed the support of the Montenegrin people for a continuation of political ties with Serbia, though in the form of a federation. Granted, the public consultation itself was marred by boycotts and social turmoil, but it did enable thenPrime-Minister Milo Đukanović to drape himself in the success of a plebiscite yielding an overwhelming $95 \%$ of the votes in support for a form of administrative union with the Serbs, with a turnout of two-thirds of all eligible voters. EC monitoring was not present then, while the referendum question was, in our view, "loaded", which makes it rather difficult to connect the vote to our topic of interest at this time, or to make any pertinent claims on the legitimacy thereof (Bideleux and Jeffries, 2007, pp. 477-478). At the same time, Montenegro began ridding itself of its communist symbolism, including the renaming of its capital to 
Issue no. $25 / 2018$

Podgorica and the adoption of a separate (albeit similar) flag from those of Serbia (Morrison, 2008, p. 68).

The road to Montenegrin independence was chiefly paved amid the popular discontent emerging from the wars in Bosnia and Croatia, where the involvement of Montenegro in the operations led by the Serbs prompted the need to reassess the initial closeness between Milo Đukanović and Slobodan Milošević. Nonetheless, the geopolitical importance of the sea-adjacent province and the unity message sent after the aforementioned referendum remained of some significance to Milošević. The Montenegrin leader started to part from the controversial Milošević as of 1996, by means of a range of economic and political reforms, of which one would have a long-term impact on the subsequent EU integration file, namely the adoption of the Deutsche Mark as Montenegro's currency in 1999, in fact already largely in use across the province experiencing at the time a fiscal deficit of 20\% (Liebscher et al., 2005, p. 165).

After becoming president of Montenegro in 1998 and taking the place of Momir Bulatović, a faithful ally of Milošević, Đukanović proceeded to a much more decided separation from Serbia, notably in the aftermath of the 1999 Kosovo campaign. In his reforming strategy, entitled "Platforma za redefiniciju odnosa Crne Gore i Srbije", he pushed for a redefinition of the duet, whilst not yet abandoning the bicephalic relationship. This, however, occurred soon after, as Milošević's grasp on power in Serbia started dwindling in late 2000, and the process met with several intermediary steps towards full independence. The most significant of these, from a constitutional standpoint, was the Belgrade Agreement of 2002, witnessed by the High Representative of the EU, Javier Solana, transforming the Federal Republic of Yugoslavia (a name which had become largely tainted at international level) into a loose union of Serbia and Montenegro, two republics placed on equal footing and governed by a confederate system. The deal had been brokered by the EU, which acknowledged the differences between the two entities, but pondered their chances to seek integration independently, as opposed to a common endeavour, eventually favouring the latter approach. Nevertheless, given the reluctance of Serbia to cooperate with the International Criminal Tribunal for the former Yugoslavia at the time, any prospects of a 
Issue no. $25 / 2018$

Stabilization and Association Agreement concluded between the EU and Serbia and Montenegro were postponed in 2004 (Kim, 2005).

In spite of the signing of the Belgrade Agreement, the Constitutional Charter of Serbia and Montenegro adopted on 4 February 2003 did little more than to prolong the already loose union between the two entities and its text actually presented itself as a rather provisional federal entente, since it enabled either of them to opt for independence under the stipulated conditions (Braniff, 2011, pp. 141-142). The institutional setup provided for a President as head of state, elected by a common parliamentary body composed of 126 members, for a five-year term. As for the common policies, apart from a fairly unitary approach to defence and foreign affairs, managed by an undersized five-member Council of Ministers, led by the President, most economic and administrative guidelines became separated, paving the way for effective self-management (Bideleux and Jeffries, 2007, pp. 500-501).

In addition to the ghosts of the Milošević era, the internal tensions within the union were augmented with the assassination of Serbian PM Zoran Đinđić, in March 2003. This, combined with the economic and administrative autonomy of the two entities and the proindependence feelings reflected by a significant share of the political spectrum, prompted the decision by Montenegro to trigger its recently-acquired constitutional prerogative to hold an independence referendum (Republic of Montenegro Referendum on State-Status, 2006) in 2006. The public consultation of 21 May 2006 yielded a narrow result, as the 55\% threshold agreed by Montenegrin PM Milo Đukanović with the EU needed for its validation was barely attained (55.5\%), amid impressive turnout (86.5\%). This, in itself, was somewhat controversial, since Đukanović had previously declared that any pro-independence majority result would prompt him to declare separation from Serbia.

The legitimacy of the process was acknowledged by the European Union, under whose monitoring it had unfolded, through the voice of HR Javier Solana, as well as by the OSCE, leading to swift international recognition, including from Serbia. In this context, the formal declaration of independence was uttered on 2 June 2006, completing the protracted process (Fruhstorfer and Hein, 2016, p. 295). 
Issue no. $25 / 2018$

\section{Montenegro's Euro-Atlantic integration process}

The subsequent part of our study focuses on Montenegro's road to NATO, serving as a premise for the Euro-Atlantic commitment of the country and as a clear indication of its stance in international affairs. It is also apparent that, similarly to the case of other countries in the region, NATO integration was often regarded as a prerequisite for the notably more complex EU bid, indicating a major shift from the past and, in the current case, from the thorny file of Yugoslavia. In effect, soon after the proclamation of independence, the Montenegrin government opened a NATO mission in Brussels and granted the Alliance's troops permission to cross its sovereign territory. Further commitments in this respect included the modernisation of its arsenal and military technology, along with the deployment of troops to hotspots like Afghanistan and Somalia. Montenegro quickly moved to adopt the IPAP in 2008 and the Adriatic Charter, which would become the principal US-driven vehicle for the integration of countries in the West Balkans into the Alliance (Albania and Croatia, in 2009, then Montenegro itself, in 2017) (Banović, 2016, pp. 78-80). The negotiations with NATO were intensified by PM Milo Đukanović at the Bucharest and, later, at the Newport/Cardiff summits, of 2008 and 2014, respectively, culminating with the formal invitation issued on 2 December 2015 (NATO, 2015). While benefitting from an observer status, Montenegro saw the ratification of its file completed by 5 June 2017, which became the official accession date.

In actuality, the candidacy had benefitted from ample support not only on the part of the United States, but also from other more or less prominent members of the Alliance, such as Germany, Romania and Turkey, as well as two ex-Yugoslav nations, Croatia and Slovenia. On the other hand, Russia's involvement in Montenegrin politics with the aim of thwarting the process became apparent judging by the stark opposition expressed in this regard by sympathetic local parties. Nevertheless, the most severe incident occurred on 16 October 2016, on election day, when an alleged coup attempt led to the arrest of 20 Serbian and Montenegrin citizens, who were subsequently connected to Russian nationals (The Guardian, 2016). Following the investigation of the Montenegrin authorities, the Supreme Court charged 14 on the count of planning a terrorist coup, apparently meant to assassinate PM Đukanović (who later tendered his resignation) and, thus, hinder the country's Euro-Atlantic 
Issue no. $25 / 2018$

integration process, swaying it towards Russia. The credibility of the allegations, doubted by local opposition parties, was somewhat bolstered by several arrests made in Belgrade on 26 October, with the Serbian government announcing that the suspects had conducted illegal surveillance of Đukanović and transmitted risky information pertaining to his schedule to third parties, for criminal reasons (BBC News 2, 2016). It is to be noted that Russia denied any involvement in the plot and qualified the allegations to the contrary made by Montenegrin prosecutor Milivoje Katnić as absurd and unsubstantiated (BBC News 2, 2017).

While this file remains somewhat unclear, it is beyond doubt that Russia's rhetoric regarding Montenegro's NATO accession bid can only be qualified as hostile, albeit in keeping with a "second cold war" discourse that has marred NATO-Russia relations for the past years. The threat of severe repercussions upon the pursuit of the process would attain its zenith in 2014, as Montenegro chose to enforce the sanctions adopted by the EU against Russia. According to a bullyish statement by the Russian Ministry of Foreign Affairs, "In the light of the hostile course chosen by the Montenegrin authorities, the Russian side reserves the right to take retaliatory measures on a reciprocal basis. In politics, just as in physics, for every action there is an opposite reaction" (Reuters 2, 2017). Additional forms of harassment on the part of the Kremlin included an embargo on Montenegrin wine (one fifth of the country's wine exports having been directed towards Russia), for alleged "sanitary" reasons (BBC News 1, 2017), which PM Duško Marković qualified as politically driven. Verbal harassment also ensued, as on 5 June 2017, i.e. the day of Montenegro's official accession to NATO, the Russian government qualified the endeavour as a "hostile course" and "antiRussian hysteria" (Reuters 2, 2017). Meanwhile, the significance of the event was underlined by NATO Secretary-General Jens Stoltenberg, who referred to it as "historic", while US Under Secretary of State Thomas Shannon praised Montenegro "for asserting its sovereign right to choose its own alliances even in the face of concerted foreign pressure" (NATO, 2017).

The accession of the country to NATO was, therefore, not exempt from controversy, some of which had been dissipated by Milo Đukanović during an interview with Radio Free Europe, on 15 December 2015, in which he clarified his country's position towards the Russian Federation. In an interview with the Bosnian newspaper Dnevni Avaz (Daily Voice), 
Issue no. $25 / 2018$

Russian Foreign Minister Sergei Lavrov had stated that: "With regards to the expansion of NATO, I see it as a mistake, even a provocation in a way. This is, in a way, an irresponsible policy that undermines the determination to build a system of equal and shared security in Europe, equal for everyone regardless of whether a country is a member of this or that bloc." Speaking to Radio Free Europe, Đukanović voiced criticism with regard to the strong-worded reaction the Kremlin traditionally resorted to on matters of NATO enlargement and gave assurances that Montenegro would not be a friend of Russia within the Alliance, whilst hinting at other member states which may not share the same opinion. In the PM's view, the rhetoric emanating from Moscow was a consequence of a general deterioration of bilateral relations between NATO and Russia, in the complicated international context at the time, revolving around Crimea (Radio Free Europe/Radio Liberty, 2015). It is not to be forgotten that economic ties between Montenegro and Russia remain quite significant, albeit not necessarily from the viewpoint of trade, but Russian money, investments and land ownership in the touristic country are far from negligible (Bugajski, 2009, p. 169).

As far as Montenegrin society is concerned, NATO integration has been a fairly divisive topic, with considerable occurrence in the public debate and in political speeches, in part as a consequence of the not too distant NATO bombings of Montenegrin territory during the 1999 Kosovo campaign (Banović, 2016, p. 157). In fact, it is only very recently (on 21 March 2018) that the Montenegrin Parliament finally ratified the border demarcation agreement with Kosovo, amid controversy and political scandals. Đukanović's Democratic Party of Socialists of Montenegro and the Social Democratic Party remain the most vivid supporters of NATO integration on the surprisingly intricate and ramified political stage of the country. As for the principal opposition forces, one encounters the Serb political groups, which, along with voices from the Russian diplomatic corps, incessantly asked for a referendum to be held on this topic of national interest, as it had been the case with some countries in the region, such as Hungary or Slovenia. Nonetheless, in the Montenegrin case, the general elections of 16 October 2016, in the absence of a referendum, became to some degree the indicator of the people's options in this respect, with the Democratic Party of Socialists emerging victorious with $41 \%$ of the votes, still short of an outright majority (OSCE, 2017). With Duško Marković assuming the position of Prime-Minister, the pursuit of 
Issue no. $25 / 2018$

the pro-NATO and pro-EU agenda was no longer questioned, all the more so because veteran Đukanović had made a point of associating, in the collective conscience, the outcome of the vote with the decisive path the country was going to take in matters of foreign policy. The pathos Đukanović put into the campaign, reminding of the black-or-white fallacy but with some grain of truth to it, engendered two possible, certainly antagonistic options, one heading towards the modernisation of the country, portrayed by Euro-Atlantic integration, while the other convened images of Russia's hegemonic attitude towards its former sphere of influence (BBC News 1, 2016).

\section{Modernising endeavours on the way to $\mathrm{EU}$ integration}

Similar to other countries in the broader East-Central region, Montenegro's NATO rapprochement was furthered and even intertwined with its EU accession bid, the latter proving, as always, far more demanding in terms of convergence and reform. While the former effort proved to be swifter, on account of the threats stemming from the new geopolitical ambitions of the Russian Federation, undoubtedly drawing a different set of guidelines than the ones driving its Serbian neighbour, Montenegro's EU accession would prove to be a tortuous endeavour, marked by extraordinary change. The precedent in this case lies with two former Yugoslav countries, whose EU integration project was not only completed in a fair amount of time, but, at least in the case of Slovenia, turned into a successful pathway to modernisation and prosperity, with a record-setting adoption of the common European currency - not unilaterally, that is. The fact that Slovenia, Croatia and, even more so, Montenegro have small, somewhat manageable economies, should render the negotiations on at least some of the accession chapters less time-consuming than in the convoluted cases of Poland, Romania or just about any other country in the region. However, this rather empirical observation does not exempt the Montenegrin file from economic hurdles, some without precedent, as we shall exhibit soon, let alone from political ones.

There is a range of consecutive political events at EU level which have favoured the progress of Montenegro's integration bid, starting with the well-known decision of the Feira European Council of 19-20 June 2000, which stamped West Balkans countries as potential candidates. This initial impetus was furthered not long after by the conclusions of the 
Issue no. $25 / 2018$

Thessaloniki Council of 19-20 June 2003, which concocted an agenda for the integration of the countries in the region (Cini, Pérez-Solórzano Borragán, 2016, p. 233). Furthermore, on 22 January 2007, the Council of the EU concluded the European partnership with Montenegro, thus setting the conditions for the reforms and priority areas to be tacked in common by the two parties, with the assistance of pre-accession funds (2007/49/EC). A socalled "Stabilisation and Association Agreement between the European Communities and their Member States of the one part, and the Republic of Montenegro, of the other part" was signed on 15 October 2007 and came into force on 1 May 2010 (2007/0123(AVC)), enabling the country to enhance its trade relations with the EU and gathering considerable support on the part of national parliamentary parties. Moreover, during the Sarajevo EU-Western Balkans ministerial meeting on 2 June 2010, the Union reaffirmed its commitment to the integration of countries in the area $(\operatorname{COM}(2011))$. Montenegro's application for full membership was submitted on 15 December 2008 and subsequently accepted at the Brussels European Council of 18-19 June 2009 (European Council, 11018/1/08). As a consequence, Enlargement Commissioner Olli Rehn presented Podgorica with the questionnaire aimed at assessing the readiness of the country for integration, in December the same year. The timeline also marks the visa exemption agreement between Montenegro and the EU, entered into force on 19 December 2009, along with the similar provisions pertaining to neighbours Serbia and FYROM, as a reward for the overall progress attained by the three countries in matters ranging from border protection to justice and security reforms (European Commission Press Release Database, IP/09/1852, 2009).

By virtue of the green light given by the European Commission based on the analysis of the answers presented by the Montenegrin government, in December 2010, it awarded it the official candidate status, soon followed by the opening of negotiations, on 29 June 2012. The advent of the Juncker doctrine and the relatively slow progress of the negotiations attained during the mandates of Štefan Füle and Johannes Hahn as Commissioners for Enlargement have not prevented Montenegro from opening 30 out of the 35 chapters, including the most complex ones, prompting President Juncker to set an approximate accession date for 2025 (Euractiv, 2017). A brief analysis of the chapters reveals various optimistic prospects, ranging from the opening of particularly sensitive ones, covering 
Issue no. $25 / 2018$

agriculture, justice and human rights, while no veto appears to be looming on the part of any of the Union's member states, unlike in the case of other candidates from the former Yugoslav area. Judging by the course of negotiations so far, it appears that the most challenging topics encompass financial and budgetary matters, as well as fisheries, whilst the economic and monetary policy chapter poses an unprecedented problem in the history of EU enlargement (notwithstanding Kosovo) (Ilirjani, 2006, p. 103), with the unilateral adoption of the euro by Montenegro.

That said, it becomes important to underline the course of administrative reform undertaken by the country, as a mostly positive example in the negotiation progress of countries in the West Balkans, and as an indicator of the achievements and setbacks marking Montenegro's road to membership to date. With the 2017 report of the Commission still pending, we have directed our analysis to the latest annual progress report of the country drafted by the EU executive, issued on 9 November 2016, deeming it an objective assessment of the progress attained and the current degree of readiness (COM(2016)). As it has become customary with such analyses, the report paints both a positive and a negative picture of compliance with Community requirements. The former includes the commendable reception of the 2016 general elections, defined by transparency and endowing the newly-elected bodies of the state with the necessary degree of legitimacy that enable them to further the negotiation process, along with the reduction of bureaucracy and the uniform approach to salaries in the public sector (the law of March 2016 rendered public careers more appealing, in a country with a very low minimum wage $-288,1$ euros, which has remained unchanged for several years) (Country Economy, 2017). The latter emphasises the need to step up the pace of administrative reform and ensure more political independence of the somewhat inflated public service corps.

Some of the thorniest negotiation chapters find their echo in the report of the Commission, marking the need for additional reforms within the justice system, still marred by accusations of corruption and by the rather slow pace of judicial procedures. Albeit public sector corruption and organised crime remain grave concerns, the country was only able to endow itself with an anti-corruption agency in 2016. Other worrying points in the report pertain to the marginalised Roma communities across the country, making up $0,8 \%$ of the 
Issue no. $25 / 2018$

population according to the census of 2011, gender equality and the freedom of mass media (Statistical Office of Montenegro, 2011). As for economic convergence, apart from the controversial adoption of the single European currency, Montenegro's indicators exhibit imbalances in areas such as unemployment and public debt.

An interesting case study in the negotiation maze is undoubtedly represented by the state of the country's regional policy, which is indicative of its capacity to implement structural funds (according to chapter 22, the country is only "moderately prepared" in this respect), combined with its administrative reform programme. To set a coherent course of action for the latter, Montenegro adopted a multiannual agenda for public administration reform, spanning across the period 2016-2020, whose analysis reveals some interesting prospects (Government of Montenegro, 2016).

Since declaring its independence, Montenegro has been engaged in a steady process aiming to shrink the breadth of its administrative apparatus, thus rendering it proportional to the size of its population. A notable step was met in 2012, when the number of public authorities was reduced to 55, of which 16 ministries, with some feeble attempts at decentralisation and a mostly centralised system of checks, partly explained by the reduced size of the country's territory. With an estimated population of 642,550, according to the CIA World Factbook (2018), the country has made it a top priority to create a sense of involvement of citizens in decision-making, by means of NGOs, democratic bodies such as the Ombudsman, as well as an enhanced e-governance service, which is superior to that of neighbouring countries (United Nations, 2016). In a rather prosaic tone, the Public Administration Reform Strategy in Montenegro 2016-2020, available in English, pleads for more meritocracy in public administration and for a clearer separation between political and technocratic positions, whilst encouraging public servants to engage in professional training.

It goes without saying that one of the top priorities of the Montenegrin government in relation to the European Union pertains to the absorption of pre-accession funds, as it is clearly reflected by the aforementioned strategy, which engenders a strong focus on administrative capacity. The financial allocations from the Community budget have been quite generous to date, with 408,5 million euros granted in the period 1998-2010 alone (SEC(2010)). As for the current multiannual framework, Montenegro is eligible for 270,5 
Issue no. $25 / 2018$

million euros under the IPA II, for the 2014-2020 period, not including the cross-border cooperation initiatives, but encompassing such priority sectors as: democracy and governance, rule of law and fundamental rights, environment and climate action, transport, competitiveness and innovation, education, employment and social policies, agriculture and rural development, as well as regional and territorial cooperation (European Neighbourhood Policy and Enlargement Negotiations, EC, 2018). The managerial burden of this funding has so far fallen to the Ministry of Foreign Affairs and European Integration, albeit the country does need to prepare itself for the eventual implementation of structural funds, upon accession. It becomes apparent that one of the potential flaws of the Public Administration Reform Strategy lies in the fact that it does not provide a single, coherent and well-defined authority meant to ensure the transition from the Instrument for Pre-Accession to the far more complex (and necessary) structural funds, in the guise of a Ministry of European Funds, if we are to take into account the cases of Romania and Croatia. In exchange, the strategy envisaged gives rise to four levels of management of structural instruments, namely: a management authority, a certification authority, an auditor and a set of intermediary bodies.

Nevertheless, such prospects should be placed on hold until Montenegro succeeds in coping with its macroeconomic challenges, such as the ever-problematic budget deficit, which, for 2018, has been prognosed at $2.6 \%$ of GDP, i.e. down from $4.2 \%$ in the previous year, and in keeping with EU norms of fiscal discipline (Reuters 1, 2017). Montenegro's 23 municipalities, including the capital, Podgorica, and the royal capital, Cetinje, are mostly affected by high levels of public debt and oversized administration. It is not to be forgotten that the country pledged to comply with Donald Trump's request to spend $2 \%$ on defence, as a NATO member, which the Montenegrin government expects to achieve by 2024 (Reuters 2, 2017). Also in the realm of its economic landscape, the country still faces the hurdles of a grey economy, leading to tax evasion, which is why the 2016-2020 strategy dedicates considerable room to control mechanisms and more effective public procurement laws, whose concrete implementation remains to be seen. 
Issue no. $25 / 2018$

\section{Some conclusions}

Montenegro's case, although far from simple, exhibits both commonalities and dissimilarities to its former Yugoslav neighbours and fellow EU candidates. While Serbia's path to NATO is blurred and EU rapprochement advances steadily, Montenegro's firm commitment to the former has enabled it to be somewhat one step ahead in its thorough reform process, however still with no clear EU accession date in sight. The size of the country partly accounts for the - if not simplicity - then the less tangled course of negotiations on its Euro-Atlantic path, as the country's 81-strong Parliament and recent constitution (2007) theoretically function within the democratic and market-economy-based parameters required by its (mostly) western international partners (Bieber, 2013, p. 120). The one significant element left in Montenegro's refurbished political landscape was prestige, which it dwelled upon when its legislative decided to pass a Law on the Status of the Descendants of the Petrović Njegoš Dynasty, namely on 12 July 2011, thus acknowledging the support and importance of its former royal house in recent endeavours aimed at obtaining the country's independence and at consolidating its identity and stance at international level (Kolstø, 2016, p. 124).

The mostly centre-left-dominated political class of Montenegro has indeed come a long way from the troublesome context of the mid-1990's, but the path to EU integration remains sinuous, not only because of the reluctance of the current European Commission to step up the pace of the accession process, but also given the nature of some of the problems identified in the negotiation chapters. Podgorica has been engaged in a thorough reform endeavour and has attempted to render it visible and transparent, including through the translation of major policy documents in English, the involvement of its young NGO sector in the modernisation process and the adoption of modern, EU-fashioned e-governance and decentralisation administrative models, relying on simplification and, hopefully, meritocracy.

The fairly stable political climate has provided EU negotiations with some degree of stability and predictability, which enables us to forecast that we may have analysed the case of the next country to break through the Juncker barrier and replenish the numerical gap (little can it compensate for the UK's presumed future departure, from other viewpoints) that would once again make the EU a 28-strong entity. Whether the unprecedented euro currency 
Issue no. $25 / 2018$

file can be resolved, with a potential merger of the Maastricht criteria into the classic convergence criteria, and whether the justice and fundamental rights chapters will be considered satisfactory in the next Commission reports, it remains to be seen. However, one should not cast aside the message than the integration of a new state into the EU (especially from the West Balkans) would send a powerful signal amid the crisis the Union is going through - that it remains a desirable, frequentable and dynamic construct, ready to once again shed itself of the regrettable fortress-Europe label and to present countries in the region with a solid pro-western option, at a time when other temptations lurk in the diametrically opposite shadows.

\section{Bibliography}

1. ALGER, O. (2016), Montenegro History and Culture: Early History, Montenegro and Serbia Period, Separation Process and History, Self- Sovereignty, People, and Environment, Tourism, CreateSpace Independent Publishing Platform.

2. BANOVIĆ, B. (2016), The Montenegrin Warrior Tradition: Questions and Controversies over NATO Membership, Springer.

3. BIDELEUX, R.; JEFFRIES, I. (2007), The Balkans: A Post-Communist History, Routledge.

4. BIEBER, F. (2013), The party system of Montenegro, In: V. STOJAROVÁ; P. EMERSON, (eds.), Party Politics in the Western Balkans, Routledge.

5. BRANIFF, M. (2011), Integrating the Balkans: Conflict Resolution and the Impact of EU Expansion, I.B.Tauris.

6. BUGAJSKI, J. (2009), Dismantling the West: Russia's Atlantic Agenda, Potomac Books.

7. CINI, M.; PÉREZ-SOLÓRZANO BORRAGÁN, N. (2016), European Union Politics, Oxford University Press.

8. CORPADEAN, A. (2018), Les fondements de la bonne gouvernance au Monténégro dans le contexte de son intégration euro-atlantique, In: S. MIȘCOIU (ed.), La « bonne gouvernance », peut-elle freiner le recul démocratique contemporain?, Larcier-Bruylant, (publication pending). 
Issue no. $25 / 2018$

9. FRUHSTORFER, A; HEIN, M (2016), Constitutional Politics in Central and Eastern Europe: from Post-Socialist Transition to the Reform of Political Systems, Springer.

10. HERT,A, L.-M. (2012), De la relațiile româno-sârbe la relațiile româno-iugoslave. Interpretări constructiviste, EFES, Cluj-Napoca.

11. HERT,A, L.-M. (2015), The Violent Conflicts in Former Yugoslavia and the Vacillations of The West: Transatlantic Discourse Constructions of the Yugoslav Wars, Online Journal Modelling the New Europe, Issue no. 17, December.

12. HÖGGER, D. (2015), The Recognition of States, LIT Verlag Münster.

13. ILIRJANI, A. (2006), The Euro Before the EU?: an Estimate of the Economic Effects of Euroization in the Western Balkans, Globic Press.

14. KIM, J. (2005), Serbia and Montenegro Union: Prospects and Policy Implications, Report for US Congress, 2 February, https://fas.org/sgp/crs/row/RS21568.pdf, last access: 18 March 2018.

15. KOLSTØ, P. (2016), Strategies of Symbolic Nation-building in South Eastern Europe, Routledge.

16. LIEBSCHER. K.; CHRISTL, J.; MOOSLECHNER, P.; RITZBERGERGRUNWALD, D. (eds.) (2005), European Economic Integration and South-East Europe: Challenges and Prospects, Edward Elgar Publishing.

17. MORRISON, K. (2008), Montenegro: A Modern History, I.B.Tauris.

18. Alliance invites Montenegro to start accession talks to become member of NATO, NATO documents, 2 December 2015, http://www.nato.int/cps/en/natohq/news_125370.htm, last access: 30 March 2018.

19. Brussels European Council, 19/20 June 2008, Presidency Conclusions, Brussels, 17 July 2008, 11018/1/08, http://www.consilium.europa.eu/ueDocs/cms_Data/docs/pressData/en/ec/101346.pdf, last access: 30 March 2018.

20. CIA World Factbook, Montenegro, https://www.cia.gov/library/publications/theworld-factbook/geos/mj.html, last access: 30 March 2018. 
Issue no. $25 / 2018$

21. Commission Opinion on Serbia's application for membership of the European Union,

$\begin{array}{lllll}\text { Brussels, } & 12 & \text { October } & \text { 2011, } & \operatorname{COM}(2011)\end{array}$ http://www.europa.rs/upload/Report\%202011.pdf, last access: 30 March 2018.

22. Commission Staff Working Document, Montenegro 2016 Report Accompanying the document "Communication from the Commission to the European Parliament, the Council, the European Economic and Social Committee and the Committee of the Regions", 2016 Communication on EU Enlargement Policy, COM(2016) 715 final, Brussels, 9 November 2016 ,

https://ec.europa.eu/neighbourhoodenlargement/sites/near/files/pdf/key_documents/2016/20161109_report_montenegro.pdf, last access: 30 March 2018.

23. Communication from the European Commission to the European Parliament and the Council, Commission Opinion on Montenegro's application for membership of the European Union, SEC(2010) 1334, Brussels, 9 November 2010, https://ec.europa.eu/neighbourhoodenlargement/sites/near/files/pdf/key_documents/2010/package/mn_opinion_2010_en.pdf, last access: 30 March 2018.

24. Council Decision of 22 January 2007 on the principles, priorities and conditions contained in the European Partnership with Montenegro (2007/49/EC), Official Journal of the European Union, 27 January 2007, https://eur-lex.europa.eu/legalcontent/EN/TXT/HTML/?uri=CELEX:32007D0049\&from=EN, last access: 30 March 2018. 25. E-government Survey, United Nations, New York, 2016, http://workspace.unpan.org/sites/Internet/Documents/UNPAN97453.pdf, last access: 30 March 2018.

26. EU advances membership talks for Montenegro, Serbia, Euractiv, 12 December 2017, https://www.euractiv.com/section/enlargement/news/eu-advances-membership-talks-forserbia-montenegro, last access: 30 March 2018.

27. Montenegrin PM Djukanovic: NATO Offer Need Not Harm Ties with Russia, Radio Free Europe/Radio Liberty, https://www.youtube.com/watch?v=Nd_eoyrFMdU, 15 December 2015, last access: 30 March 2018. 
28. Montenegro - financial assistance under IPA II, European Neighbourhood Policy and Enlargement Negotiations, European Commission, https://ec.europa.eu/neighbourhoodenlargement/instruments/funding-by-country/montenegro_en, last access: 30 March 2018.

29. Montenegro approves NATO membership as Russia protests, BBC News, 28 April 2017, http://www.bbc.com/news/world-europe-39738238, last access: 30 March 2018.

30. Montenegro election: Djukanovic declares ruling party victory, BBC News, 17 October 2016, http://www.bbc.com/news/world-europe-37672752, last access: 30 March 2018.

31. Montenegro passes 2018 budget, reducing deficit, Reuters, 27 December 2017, https://www.reuters.com/article/montenegro-budget/montenegro-passes-2018-budgetreducing-deficit-idUSL8N1OR12D, last access: 30 March 2018.

32. Montenegro, Parliamentary Elections, 16 October 2016: OSCE Final Report, 25 January 2017, https://www.osce.org/odihr/elections/montenegro/295511, last access: 30 March 2018.

33. Montenegro's PM quits after suggesting Russia had role in election plot, The Guardian, 25 October 2016, https://www.theguardian.com/world/2016/oct/25/montenegroinvestigating-russia-alleged-election-coup-plot, last access: 30 March 2018.

34. National Minimum Wage - Montenegro, Country Economy, 2017, http://countryeconomy.com/national-minimum-wage/Montenegro, last access: 30 March 2018.

35. Public Administration Reform Strategy in Montenegro 2016-2020, Government of Montenegro, July 2016 , http://www.mna.gov.me/ResourceManager/FileDownload.aspx $?$ rid=268749\&rType=2\&file= PUBLIC\%20ADMINISTRATION\%20REFORM\%20STRATEGY\%20IN\%20MONTENEG RO\%202016-2020.pdf, last access: 30 March 2018.

36. Remarks by NATO Secretary General Jens Stoltenberg at the Montenegro accession $\begin{array}{lllll}\text { ceremony, NATO } & \text { documents, } & 7 & \text { June }\end{array}$ http://www.nato.int/cps/en/natohq/opinions_144737.htm, last access: 30 March 2018.

37. Republic of Montenegro Referendum on State-Status 21 May 2006, OSCE/ODIHR Referendum Observation Mission Final Report, Warsaw, 4 August 2006, 
Issue no. $25 / 2018$

https://www.osce.org/odihr/elections/montenegro/20099?download=true, last access: 30 March 2018.

38. Russia rejects claim of Montenegro plot, BBC News, 20 February 2017, http://www.bbc.com/news/world-europe-39027315, last access: 30 March 2018.

39. Russia threatens retaliation as Montenegro becomes $29^{\text {th }}$ NATO member, Reuters, 6 June 2017, http://www.reuters.com/article/us-usa-nato-montenegro-idUSKBN18W2WS, last access: 30 March 2018.

40. Serbia arrests group for 'spying on Montenegro PM', BBC News, 25 October 2016, http://www.bbc.com/news/world-europe-37764935, last access: 30 March 2018.

41. Stabilisation and Association Agreement between the European Communities and their Member States of the one part, and the Republic of Montenegro, of the other part, Council of the European Union, Brussels, 21 September 2007, 2007/0123(AVC), http://register.consilium.europa.eu/doc/srv?l=EN\&f=ST\%2011566\%202007\%20INIT, last access: 30 March 2018.

42. Statistical Office of Montenegro, Census 2011 data, https://www.monstat.org/eng/page.php?id=393\&pageid=57, last access: 30 March 2018.

43. Visa free travel for citizens of the former Yugoslav Republic of Macedonia, Montenegro and Serbia before Christmas, European Commission Press Release Database, Brussels, 30 November 2009, IP/09/1852, http://europa.eu/rapid/press-release_IP-091852_en.htm, last access: 30 March 2018. 